\title{
"MENINGKATKAN SISTEM PEMBINAAN WARGA BINAAN PEMASYARAKATAN DI LEMBAGA PEMASYARAKATAN (LAPAS) SEBAGAI UPAYA UNTUK MEMAKSIMALKAN PENEGAKAN HUKUM“"
}

\author{
Rohmad Taufiq \\ Wartawan Kilas Fakta \\ taufiq211@yahoo.co.id
}

\begin{abstract}
That the Indonesian state constitution guarantees human rights. All citizens together with their position in law and government and must uphold the law and government with no exception. Everyone has the right to the recognition, guarantee, protection and fair legal certainty, and equal treatment before the law deprivation of liberty in the form of punishment marks the reduction of most of the rights of the convicted person.

In the criminal justice system in Indonesia, correctional institutions are one of the pillars in implementing law enforcement.in essence the prisoners are as human beings and human resources who must be treated well and humanely in an integrated coaching system. In the correctional system there are two missions and goals to be achieved. First, as a punishment (punishmen), namely an effort to implement enforcement, legal certainty and to cause a deterrent effect second, as an improvement (treatment) which is an effort directed to education, coaching, training and prevention which all lead to the goal of improving the preparation and enlightening of the future of prisoners. The treatment of prisoners is based on Pancasila and the 1945 constitution, which is the final part of the criminal system.in this case the penitentiary system is a series of law enforcement that aims to make prisoners aware of their mistakes, improve themselves and not repeat the crime, so that they can be accepted again by the community, can actively play a role in development and can live fairly as good, righteous citizens and responsible.
\end{abstract}

Key word: Guidance, correctional institution, law enforcement 


\section{A. Pendahuluan}

Pembangunan suatu bangsa memerlukan aset pokok yang disebut sumber daya (Resources), baik sumber daya alam (Natural Resources), maupun sumber daya manusia (human Resources). Kedua sumber daya tersebut sangat penting dalam menentukan keberhasilan suatu pembangunan. Tetapi apabila dipertanyakan mana yang lebih penting diantara kedua sumber daya tersebut, maka sumber daya manusialah yang lebih penting. Hal ini kita dapat amati dari kemajuan-kemajuan dari suatu bangsa dan Negara sebagai indikator keberhasilan pembangunan bangsa tersebut. Negara-negara yang potensial miskin sumber daya alamya seperti jepang dan korea tetapi karena usaha peningkatan kualitas sumber daya manusianya begitu hebat, maka kemajuan bangsa tersebut dapat kita saksikan dewasa ini. Sebaliknya Negara-negara yang potensial kaya akan sumber daya alamnya seperti Negara-negara timur tengah tetapi karena kurang mementingkan pengembangan sumberdaya manusianya, maka kemajuannya relatif kalah dengan bangsa dan Negara tersebut.

Berbicara masalah sumber daya manusia, sebenarnya dapat kita lihat dari dua aspek, yaitu kuantitas dan kualitas. Kuantitas menyangkut jumlah sumber daya manusia (penduduk), yang kurang penting kontribusinya dalam pembangunan, dibandingkan dengan aspek kualitas. Bahkan kuantitas sumber daya manusia yang tanpa disertai dengan kualitas yang baik justru akan menjadi beban pembangunan suatu bangsa dan Negara. Sedangkan kualitas menyangkut mutu sumber daya manusia tersebut, yang meliputi kemampuan (skiil), baik kemampuan fisik maupun keampuan non fisik (kecerdasan dan mental). Oleh sebab itu untuk kepentingan akselerasi suatu pembangunan di bidang apapun, maka peningkatan kualitas sumber daya manusia merupakan suatu prasarat yang sangat penting dan utama.

Kualitas sumber daya manusia ini, menyangkut dua aspek, yakni aspek fisik dan aspek non fisik. Aspek non fisik meliputi kemampuan berfikir, kemampuan bekerja maupun kemampuan keterampilan-keterampilan lainnya. Oleh sebab itu, upaya meningkatkan kualitas sumber daya manusia juga dapat diarahkan kepada kedua aspek tersebut. Untuk meningkatkan kualitas fisik dapat di upayakan melalui program-program pangan, kesehatan dan gizi. Sedangkan untuk meningkatkan kualitas atau kemampuan non fisik, maka upaya pendidikan dan pelatihan adalah hal yang paling 
diperlukan. Upaya inilah yang dimaksudkan dengan pengembangan sumber daya manusia.

Manusia pada hakikatnya adalah makluk sosial, dimana secara naluri manusia itu ingin hidup berkelompok atau bermasyarakat. Manifestasi dari kehidupan berkelompok ini antara lain menimbulkan adanya organisai-organisasi atau lembagalembaga sosial yang ada. Didalam organisasi itu setiap anggota individu dapat berperan dan memenuhi sebagian dari kebutuhannya antara lain kebutuhan menampakkan harga diri dan status sosialnya. Manusia baik sebagai mahluk individu maupun sebagai makhluk sosial mempunyai berbagai macam kebutuhan material maupun kebutuhan non material. Abraham Maslow, mengklasifikasikan kebutuhan manusia itu dalam tingkatan kebutuhan, yang selanjutnya disebut dengan hierarki kebutuhan (Soekidjo Notoatmojo, 2003).

Pengembangan sumber daya manusia secara makro adalah sangat penting dalam rangka mencapai tujuan-tujuan pembangunan secara efektif. Pengembangan sumber daya manusia yang terarah dan terencana disertai dengan pengelolaan yang baik akan dapat menghemat sumber daya alam, atau setidak-tidaknya penglahan dan pemakaina sumber daya alam dapat secara berdaya guna dan berhasil guna. Demikian pula dengan pengembangan sumber daya manusia secara mikro disuatu organisasi atau lembaga akan sangat penting dalam mencapai tujuan dan hasil kerja yang optimal. Baik secara makro maupun mikro pengembangan sumber daya manusia merupakan bentuk infestasi (human invesment), dalam kontek ini proses pengembangan sumber daya manusia merupakan suatu condition sine quanon, yang harus ada dan terjadi di suatu lembaga atau organisasi. Namun demikian dalam pelaksanaan pengembangan sumber daya manusia ini perlu mempertimbangkan factor-faktor baik dari dalam diri organisasi itu sendiri maupun dari luar organisasi yang bersangkutan (internal dan eksternal).

Faktor internal disini mencakup keseluruhan kehidupan organisasi yang dapat dikendalikan baik oleh pimpinan maupun oleh anggota organisasi yang bersangkutan, seperti visi misi dan tujuan organisasi, strategi pencapaian tujuan, sifat dan jenis kegiatan, dan jenis teknologi yang digunakan. Faktor eksternal dalam hal ini organisasi itu berada didalam lingkungan dan tidak dapat terlepas dari pengaruh lingkungan organisasi itu berada. Agar organissi itu melaksanakan visi misi dan tujuannya, maka ia harus 
memperhatikan dan memperhitungkan adanaya faktor-faktor lingkungan, seperti kebijaksanaan pemerintah, sosio budaya masyarakat serta perkembangan ilmu pengetahuan dan teknologi.

\section{B. Pembahasan}

Hubungan masyarakat dan hukum dapat dipahami melalui adagium tentang hubungan hukum dengan masyarakat sebagaimana dicetuskan oleh cicero satu abad sebelum masehi, yaitu ubi societies, ibi ius yang berarti bahwa tiada masyarakat tanpa hukum dan tiada hukum tanpa masyarakat (Mahmutarum, 2010). Hukum diciptakan masyarakat untuk mengatur kehidupan masyarakat dalam rangka menciptakan tatanan dalam masyarakat yang damai dan bahagia. Hal ini dapat diartikan sebagai suatu bentuk hubungan masyarakat hukum masyarakat. Hukum dibentuk oleh dan diberlakukan untuk masyarakat. Adagium ini dibenarkan oleh kenyataan kehidupan dari setiap tipe masyarakat. Keberadaan hukum adat dalam masyarakat pedesaan yang masih hidup dalam struktur yang masih sederhana, hukum nasional untuk suatu bangsa dan bernegara dan hukum internasional dalam masyarakat internasional, kesemuanya merupakan bukti pembenaran adagium tersebut.

Bagi Negara Indonesia yang berdasarkan pancasila, pemikiran-pemikiran baru mengenai fungsi pemidanaan yang tidak lagi sekedar penjeraan tapi juga merupakan suatu usaha rehabilitasi dan reintegrasi sosial warga binaan pemasyarakatan telah melahirkan suatu sistem pembinaan yang sejak lebih dari tiga puluh tahun yang lalu dikenal dan dinamakan sistem pemasyarakatan. Walaupun diadakan berbagai perbaikan mengenai tatanan atau (stelsel) pemidaan seperti pranata pidana bersyarat (Pasal 14a KUHP), pelepasan bersyarat (Pasal 15 KUHP) dan pranata khusus penuntutan serta penghukuman terhadap anak (Pasal 45, 46, dan 47 KUHP), namun pada dasarnya sifat pemidaan masih bertolak dari asas dan system pemenjaraan, system ini sangat menekankan pada unsur balas dendam dan penjeraan, sehingga institusi yang dipergunakan sebagai tempat pembinaan adalah rumah penjara bagi narapidana dan rumah pendidikan negara bagi anak yang bersalah.

System pemenjaraan yang sangat menekannkan pada unsur balas dendam dan penjeraan yang disertai dengan lembaga " rumah penjara" secara berangsur angsur dipandang sebagai suatu system dan sarana yang tidak sejalan dengan konsep rehabilitasi dan 
reintegrasi sosial, agar narapidana menyadari kesalahannya, tidak lagi berkehendak untuk melakukan tindak pidan dan kembali menjadi warga masyarakat yang bertanggungjawab bagi diri, keluarga, dan lingkungannya. Berdasarkan pemikiran tersebut, maka sejak tahun 1964 sistem pembinaan bagi narapidana dan anak pidana telah berubah secara mendasar, yaitu dari system kepenjaraan menjadi sistem pemasyarakatan. Begitu pula insttusinya semula disebut rumah penjara dan rumah pendidikan Negara berubah menjadi Lembaga Pemasyarakatan berdasarkan Surat Instruksi Kepal Direktorat Pemasyarakatan Nomor J.H.G.8/506 Tanggal 17 Juni 1964.

Sistem Pemasyarakatan merupakan satu rangkaian kesatuan penegakan hukum pidana, oleh karena itu pelaksanaannya tidak dapat dipisahkan dari pengembangan kosepsi umum mengenai pemidanaan. Narapidana bukan saja objek melainkan juga subyek yang tidak berbeda dari manusia lainnya yang sewaktu-waktu dapat melakukan kesalah atau kekhilafan yang dapat dikenakan pidana, sehingga tidak harus diberantas. Yang harus diberantas adalah faktor-faktor yang dapat menyebabkan narapidana berbuat hal-hal yang bertentangan dengan hukum, kesusilaan, agama, atau kewajiban - kewajiban sosial lain yang dapat dikenakan pidana. Pemidaan adalah upaya menyadarkan narapidana atau anak pidana agar menyesali perbuatannya, dan mengembalikannya menjadi warga masyarakat yang baik, taat kepada hukum, menjunjung tinggi nilai-nilai moral, sosial dan keagamaan, sehingga tercapai kehidupan masyarakat yang aman, tertib dan damai.

Anak yang bersalah pembinaannya ditempatkan di Lembaga Pemasyarakatan anak. Penempatan anak yang bersalah tersebut dipisah- pisahkan sesuai dengan status mereka masing - masing yaitu anak pidana, anak Negara, dan anak sipil. Perbedaan status anak tersebut menjadi dasar pembedaan pembinaan yang dilakukan terhadap mereka. Lembaga Pemasyarakatan sebagai ujung tombak pelaksanaan asas pengayoman merupakan tempat untuk mencapai tujuan tersebut diatas melalui pendidikan, rehabilitasi, dan reintegrasi. Sejalan dengan peran Lembaga Pemasyarakatan tersebut, maka tepatlah apabila petugas pemasyarakatan yang melaksanakan tugas pembinaan dan pengamanan warga binaan pemasyarakatan menurut regulasi tentang kemasyarakatan ditetapkan sebagai pejabat fungsional penegak hukum. 
Sistem Pemasyarakatan disamping bertujuan untuk mengembalikan wraga binaan Pemasyarakatan sebagai warga yang baik, juga bertujuan untuk melindungi masyarakat terhadap kemungkinan diulanginya tindak pidana oleh warga binaan Pemasyarakatan serta merupakan penerapan dan bagian yang tidak terpisahkan dari nilai-nilai yang terkandung dalam pancasila. Dalam system Pemasyarakatan narapidana, anak didik Pemasyarakatan, atau klien pemasyarakatan berhak mendapatkan pembinaan rohani dan jasmani serta dijamin hak - hak mereka untuk menjalankan ibadahnya, berhungan dengan pihak luar baik keluarga maupun pihak lain, memperoleh informasi baik melalui media cetak maupun elektronik, memperoleh pendidikan yang layak dan lain sebagainya. Untuk melaksanakan system pemasyarakatan tersebut diperlukan juga keikutsertaan masyarakat, dengan baik mengadakan kerjasama dalam pembinaan maupun dengan sikap bersedia menerima kembali warga binaan pemasyarakatan yang telah selesai menjalani pidananya.

Dalam pembangunan dibidang hukum terutama dalam konteks penegakan hukum, pemerintah melalui Undang -Undang Republik Indonesia no. 12 tentang pemasyarakatan telah mengatur bahwa sistem pemasyarakatan merupakan rangkaian penegakan hukum yang bertujuan agar warga binaan pemasyarakatan menyadari kesalahannya, memperbaiki diri, dan tidak mengulangi tindak pidana sehingga dpt diterima kembali oleh lingkungan masyarakat, dapat aktif berperan dalam pembangunan dan dapat hidup secara wajar sebagai warga yang baik dan bertanggung jawab. Sistem pemasyarakatan merupakan suatu tatanan mengenai arah dan batas serta cara pembinaan warga binaan pemasyarakatan berdasarkan pancasila yg dilaksanakan secara terpadu antara Pembina, yang dibina, dan masyarakat untuk meningkatkan kualitas warga binaan kemasyarakatan. Sistem pemasyarakatan diselenggarakan dalam rangka untuk membentuk warga binaan pemasyarakatan agar menjadi manusia seutuhnya. Sistem pemasyarakatan berfungsi menyiapkan arga binaan pemasyarakatan agar dapat berintegrasi secara sehat dengan masyarakat, sehingga dapat berperan kembali sebagai anggota masyarakat yang bebas dan bertanggung jawab.

Pemasyarakatan merupakan kegiatan untuk melakukan pembinaan warga binaan pemasyarakatan berdasarkan sistem, kelembagaan, dan cara pembinaan yang merupakan bagian akhir 
dari sistem pemidaan dalam tata peradilan pidana. Dalam system pembinaan pemasyarakatan dilaksanakan berdasarkan asas pengayoman, persamaan perlakuan dan pengayoman, pendidikan, pembimbingan, penghormatan harkat dan martabat manusia, kehilangan kemerdekaan merupakan satu-satunya penderitaan, dan terjaminnya hak untuk tetap berhubungan dengan keluarga dan orang-orang tertentu.

Hukum dan keadilan merupakan dua hal yang tidak dapat dipisahkan. Pada saat kita membicarakan masa hukum, maka secara jelas maupun samar-samar kita akan sampai kepada masalah keadilan. Hal itu berarti bahwa hukum tidak cukup dibicarakan dalam konteksnya sebagai suatu tatanan dan konstruksi yg bersifat formal belaka, akan tetapi juga sebagai bagian dari ekspresi dan ekspektasi cita- cita masyarakat. Tujuan hukum bukan semata-mata dilihat secara legalitas formal untuk menjamin keteraturan dan konssitensi dalam pelaksanaan suatu peraturan hukum, melahirkan juga secara substansial yang melandasi pengenalan supremasi nilai-nilai kepribadian seseorang, dan sebagai institusi yang menyediakan bingkai kerja untuk mengekspresikan keadilan secara penuh (Mahmutarom, 2010).

Di Indonesia masalah adil dan keadilan mendapat perhatian dan tempat yang sangat terhormat dalam kehidupan bermasyarakat, berbangsa dan bernegara. Hal ini dapat dilihat dalam dasar filsafat Negara Pancasila yang pada sila keduanya secara jelas dan tegas menuliskan, "Kemanusiaan yang adil dan beradap", serta dalam sila kelimanya yang menyebutkan "keadilan sosial bagi seluruh rakyat Indonesia". Bahwa pancasila adalah cita hukum (Rechat sidee) yang menguasai Hukum Dasar Negara, baik hukum dasar yang tertulis maupun hukum dasar yang tidak tertulis ( A. Hamid S. Ahtamimi, 1991). Meskipun demikian sampai sekarang ini masalah pengertian, kedudukan, cakupan dan berbagai pengertian itu mengenai "Adil" dan " Keadilan" belum begitu mendapat perhatian secara rinci dan memadai, termasuk landasan teori dan dasar filsafatnya.

Kerangka pemikiran yang mengaitkan hukum dan adilan itu pulalah yang mengisyaratkan bahwa untuk mewujudkan keadilan dalam masyarakat, proses dan kualitas penegakan hukum menjadi faktor yang sangat penting dan menentukan. Proses dan kualitas penegakan hukum yang baik, benar dan adil diharapkan dapat menciptakan kehidupan masyarakat yang baik dalam suasana 
saling menghargai dan menghormati, menurut prinsip-prinsip hukum yang laku. Namun dalam kenyataannya sampai saat ini penegakan hukum di negara kita masih relatif lemah dalam mewujudkan rasa keadilan bagi masyarakat pada umumnya dan bagi para pencari keadilan pada khususnya (Mahmutarom,2010). Hukum yang seharusnya berfungsi sebagai pengayom masyarakat dengan cara memberikan keadilan melalui istrumen dan aparat penegak hukumnya ternyata belum mampu menunjukan peran dan fungsi utamanya secara baik dan benar.

Didalam system peradilan pidana di Indonesia, Lembaga Pemasyarakatan merupakan salah satu pilar dalam melaksanakan penegakan hukum. Peran dan fungsi lembaga pemasyarakatan bukanlah sebagai tempat pembuangan bagi orang - rang yang telah divonis bersalah oleh pengadilan semata, akan tetapi pada hakikatnya lembaga pemasyarakatan mempunyai peran dan fungsi yang sangat besar, yaitu sebagai sarana untuk membina masyarakat dan menyadarkan kembali orang - orang yang telah dinyatakan bersalah dalam proses pradilan oleh pengadilan, agar menjadi orang - orang yang mau dan mampu memahami dan menyadari kekhilafan dan kesalahannya (Hibnu Nugroho,2018). Sehingga pada saat pada saat selesai menjalani masa hukuman kembali ke tengah - tengah masyarakat akan dapat menjadi pribadi -pribadi baru yang lebih baik dan benar

Secara ideal dalam sistem pemasyarakatan, ada dua tujuan yang ingin dicapai, Pertama sebagai sistem dan sarana penghukuman (Punishment) dalam konteks dan bingkai semua bentuk tindakan dan perbuatan melawan hukum, sehingga dapat menumbuhkan dan meninbulkan efek jera. Kedua, sebagai sebuah upaya perbaikan (Treatment) yang berorientasi pada pembinaan, pendidikan, dan pencegahan, yang diarahkan pada tujuan pencerahan kehidupan masa depan para penghuni Lembaga Pemasyarakatan (Nara Pidana).

Sebagai sebuah institusi dan instrument penegakan hukum, Lembaga Pemasyarakatan yang baik harus dikawal oleh aparat yang mempunyai integritas, komitmen, kompetensi, karakter dan profesionalitas sesuai dengan nilai-nilai dasar filsafat pancasila. Nilai-nilai Ketuhanan yang Maha Esa, keimanan dan ketaqwaan harus selalu menjadi dasar setiap ucapan, sikap dan tindakan aparat dan penghuni lembaga pemasyarakatan. Nilai-nilai religius, etika dan karakter yang pancasilais harus selalu menjadi dasar dan 
pijakan serta tertanam dalam setiap kebijakan dan implementasi regulasi yang ada. Ada keseimbangan antara hak dan kewajiban penghuni lembaga kemasyarakat seperti yang telah diatur dengan jelas dan tegas dalam pasal 14 Ayat ( I ) Undang Undang tentang Pemasyarakatan yaitu antara lain bahwa penghuni Lembaga Pemasarakatan mempunyai hak untuk menjalankan ibadah sesuai dengan agama dan keyakinannya masing-masing, hak mendapatkan perawatan kesehatan, hak menerima kunjungan keluarga dan hak-hak lain dan yang dirumuskan secara terperinci dalam regulasi tersebut. Selain itu juga ketentuan yang diatur dalam Peraturan Pemerintah No. 99 Tahun 2012 tentang syarat dan tata cara pelaksanaan hak warga binaan Pemasyarakatan (Ibnu Nugroho, 2018). Didalam proses peradilan pidana seharusnya banyak pihak yang harus dilindungi hak dan kepentingannya, baik pelaku tindak pidana, korban maupun masyarakat dan atau Negara. Adanya ketidakseimbangan dalam perlakuan dan perlindungan hak dan kepentingan masing - masing dai kawatirkan bahwa tujuan hukum yang diantaranya adalah untuk menciptakan tata tertib dan kedamaian dalam masyarakat dan terselesaikannya konflik yang ditimbukan oleh tindak pidana tersebut, justru menjadi sulit terwujud tingkat kesulitan dan kompleksnya proses tindak pidana tersebut justru terletak pada kenyataan bahwa peradilan pidana yang senantiasa kurang menyentuh dasar - dasar dari kehidupan masyarakatdan kesejahteraan hidup manusia secara keseluruhan (Mahmutarom 2010). Oleh Karena itu kembali ke tradisi dan religi dalam upaya mencari nilai-nilai keadilan yang dapat dijadikan dasar dalam memutuskan kebijakan dibidang pembaharuan hukum, merupakan langkah yang diangap terbaik. Langkah demikian tampaknya sejalan dengan gagasan Francis Fukuyama yang menyatakan bahwa social capital merupakan landasan dalam merancang-bangun hukum yang akomodatif terhadap berbagai kepentingan, termasuk kepentingan yang bernuansa global. Pendirian ini bersumber dari pandangan bahwa rancang-bangun hukum yang menimbulkan will to power dan pemaksaan terhadap masyarakat untuk mencabut dan membuang jauh-jauh akar sosial budaya, demi proyek modernitas yang dipandang dapat mencerahkan dan membebaskan, telah terbukti gagal dalam memenuhi janji-janjinya (Mahmutarom, 2010).

Ajakan untuk kembali ke tradisi dan religi merupakan salah satu wujud keberpihakan pada pluralitas dan heterogenitas yang 
seharusnya menjadi ciri dan kerangka dasar dalam melakukan rancang-bangun hukum nasional.

\section{Penutup}

Dalam rangka meningkatkan system pembinaan warga binaan Pemasyarakatan di Lembaga Pemasyarakatan diperlukan upaya-upaya sistematis baik yang terkait dengan peningkatan kualitas sumber daya manusia, sistem dan instrument maupun sarana dan prasarana penunjang lainnya. Pada hakekatnya warga binaan Pemasyarakatan adalah sebagai insan dan sumber daya manusia yang harus diperlakukan dengan baik dan manusiawi dalam satu sistem pembinaan yang terpadu.

Bahwa perlakuan terhadap warga binaan Pemasyarakatan berdasarkan system penjaraan sudah tidak sesuai dengan system Pemasyarakatan berdasarkan Pancasila dan Undang -Undang Dasar 1945 yang merupakan bagian akhir dari system pemidanaan. Upaya peningkatan system pembinaan tidak dapat dilepaskan dari masalah integritas, Terutama integritas diri yang melekat pada setiap personel aparat yaitu selarasnya hati dengan ucapan dan tindakan oleh karena itu integritas dapat dianologikan sebagai pondasi suatu banguanan. Sebuah bangunan yang memiliki fondasi yang kuat maka bangunan yang terbentuk akan berdiri tegak dan kokoh, sebaliknya fondasi yang rapuh, sekalipun bangunan diatasnya memiliki bentuk yang sangat indah maka tidak akan mampu bertahan lama, lama-lama akan retak, tidak stabil, miring dan pada akhirnya akan roboh.

Sejak tahun 2012, komisi pemberantasan korupsi (KPK) telah meluncurkan sebuah program yang disebut dengan Sistem Intergritas Nasional (SIN). Program ini diluncurkan untuk menumbuhkan sikap anti korupsi dari akar sampai hulu disemua lini dan aspek kehidupan berbangsa dan berNegara. Tujuan utamanya adalah untuk memajukan kesejahteraan bangsa dalam konteks ini korupsi berpotensi menghalangi tujuan bangsa tersebut karena korupsi diindonesia sudah sangat menggurita hampir di semua lini dan level kehidupan bermasyarakat, berbangsa dan bernegara. Sehingga dapat menimbulkan kemiskinan yang masif dan kemarahan yang struktural (Hibnu Nugroho, 2018)

Berdasarkan pengalaman KPK dalam menangani kasus korupsi, tumbuhnya perilaku korup diakibatkan oleh lemahnya integritas baik individu, keluarga maupun instiusi serta lemahnya 
hubungan antar institusi. Grativikasi yang terjadi di Lembaga Pemasyarakatan dengan memperlakukan warga binaan secara diskriminatif akan dapat merusak dan menurunkan sistem pembinaan di dalamya. Permasalahan sel mewah ataupun perlakuan istimewa terhadap warga binaan yang mampu membayar kepada pejabat dan aparat dilingkungan Lembaga Pemasyarakatan tidak dapat dilepaskan masalah dr masalah integritas. Cita- cita luhur Pemasyarakatan telah tereduksi oleh ulah beberapa oknum pejabat dan aparat didalamnya akan tetapi semangat dan optimisme untuk menumbuhkan dan mengembangkan sikap aparat yang mempunyai integritas, komitmen dan profesionalitas harus tetap ada. Sebagai kata penutup kita harus menyadari bahwa sebaik apapun sistem pembinaan dan pengawasan di dalam Lembaga Pemasyarakatan akan tetap tidak berarti, manakala integritas, komitmen dan profesionalitas aparat hukumnya rendah, yang secara signifikan akan berpengaruh terhadap out put dari warga binaan. 
Meningkatkan Sistem Pembinaa Warga Binaan...

\section{Daftar Pustaka}

A. Hamid S. Atamimi, 1991, Pancasila Sebagai Ideologi Dalam Berbagai Bidang Kehidupan Bermasyarakat, Berbangsa dan Bernegara, Jakarta, BP7 Pusat.

Mahmutarom HR., 2010, Rekonstruksi Konsep Keadilan, Semarang, Badan Penerbit, Universitas Diponegoro.

Soekidjo Notoadmojo, 2003,Pengembangan Sumber Daya Manusia, Jakarta, Rineka Cipta.

Hibnu Nugroho, Wacana, Suara Merdeka, Sabtu, 28 Juli 2018.

Undang - Undang Republik Indonesia No. 12 tahun 1995 Tentang Pemasyarakatan, 1995, Jakarta, Sekretariat Negara. 